\title{
ANALISIS SENTIMEN PENERAPAN PSBB DI DKI JAKARTA DAN DAMPAKNYA TERHADAP PERGERAKAN IHSG
}

\author{
Amelia Syahadati' ${ }^{1)}$, Novert Cyril Lengkong ${ }^{2)}$, Ouditiana Safitri ${ }^{3)}$,Septriyan Machsus ${ }^{4)}$, \\ Yongki Ramanda Putra ${ }^{5)}$, Rani Nooraeni') \\ 1,2,3,4,5 Jurusan Statistika, Politeknik Statistika STIS \\ 1,2,3,4,5 Jl. Otto Iskandardinata No. 64C, Jakarta Timur
}

Emaill1211709540@stis.ac.id, ${ }^{2} 211709904 @ s t i s . a c . i d,{ }^{3} 211709933 @ s t i s . a c . i d,{ }^{4} 211710006 @ s t i s . a c . i d$, 5211710072@stis.ac.id, 'raninoor@stis.ac.id

\begin{abstract}
In handling the spread of Covid-19, several countries have implemented social distancing and lockdown policies. In Indonesia, one of the policies taken is PSBB. As a result many economic activities, such as production to distribution of goods and services, were disrupted. One way to see public opinion in assessing PSBB is through Twitter. Apart from being able to find out people's opinions, tweets can also be used to conduct sentiment analysis. Therefore, this study aims to: 1) analyze public sentiment regarding the Jakarta $2^{\text {ni }} P S B B$; 2) analyze the impact of this sentiment on the IHSG movement; 3) comparing the classification of several methods, logistic regression, $k$-nearest neighbor, random forest, and naïve bayes. Twitter data scraping for the period September 8 - October 9 was carried out using Orange and RStudio software. Furthermore, sentiment analysis with Orange classifies sentiment into positive and negative groups. Then, logistic regression shows that negative sentiment has a significant effect in predicting a decline in the IHSG, while positive sentiment is not significant. And from the comparison of classification methods, it was found that the logistic regression produced the highest accuracy.
\end{abstract}

Keyword:PSBB Jakarta, IHSG, Twitter, Sentiment Analysis , Binary Logistic Regression, Classification.

\begin{abstract}
Abstrak
Dalam penanganan penyebaran Covid-19, beberapa negara memberlakukan kebijakan social distancing dan lockdown. Di Indonesia, salah satu kebijakan yang diambil adalah pembatasan sosial berskala besar (PSBB). Akibat dari PSBB banyak kegiatan ekonomi seperti produksi hingga distribusi barang dan jasa terganggu. Salah satu cara melihat opini masyarakat dalam menilai PSBB adalah melalui social media Twitter. Selain dapat mengetahui opini masyarakat, kicauan atau tweets juga dapat dimanfaatkan untuk melakukan analisis sentimen. Oleh karena itu, penelitian ini bertujuan untuk : 1) melakukan analisis sentimen masyarakat terkait PSBB DKI Jakarta jilid II; 2) melihat dampak sentimen tersebut terhadap pergerakan IHSG; 3) membandingkan hasil klasifikasi beberapa metode yaitu regresi logistik, k-nearest neighbor, random forest, dan naïve bayes. Scraping data Twitter periode 8 September - 9 Oktober dilakukan dengan memanfaatkan software Orange dan RStudio. Selanjutnya, analisis sentimen dengan Orange mengklasifikasikan sentiment menjadi kelompok positif dan negatif. Lalu dibentuklah model persamaan regresi logistik biner. Hasil regresi logistik menunjukkan sentimen negatif berpengaruh signifikan dalam memprediksi penurunan IHSG, sedangkan sentimen positif tidak signifikan dalam model. Dan dari perbandingan metode klasifikasi, ditemukan bahwa metode regresi logistik menghasilkan akurasi paling tinggi.
\end{abstract}

Kata Kunci:PSBB Jakarta, IHSG, Twitter, Analisis Sentimen, Regresi Logistik Biner, Klasifikasi.

\section{Pendahuluan}

Kasus Covid-19 di Indonesia pertama kali dilaporkan pada tanggal 2 Maret 2020. Dua warga Depok yang merupakan ibu dan anak terjangkit virus corona setelah melakukan kontak dengan seorang WNA asal Jepang. Sejak saat itu kasus corona telah meningkat, dengan penambahan kasus positif yang berfluktuasi setiap harinya. Secara kumulatif kasus positif telah menyentuh angka 200.035 orang pada hari Selasa, 8 September 2020 atau 6 bulan setelah kasus pertama muncul (Satuan Tugas Penanganan Covid-19, 2020).

Untuk menekan laju penularan Covid-19 negara seperti Amerika Serikat memberlakukan aturan social distancing, sedangkan beberapa negara seperti Tiongkok, Italia, dan India memberlakukan lockdown. Indonesia 
sendiri memberlakukan Pembatasan Sosial Berskala Besar atau (PSBB). Berdasarkan Peraturan Pemerintah RI No. 21 Tahun 2020 tentang pembatasan sosial berskala besar dinyatakan bahwa PSBB dapat dilakukan ketika jumlah kasus dan/atau jumlah kematian meningkat dan menyebar secara signifikan dan cepat ke beberapa wilayah, serta terdapat kaitan epidemiologis dengan kejadian serupa di wilayah atau negara lain.

PSBB tahap pertama mulai diterapkan pada 10 April 2020 di berbagai daerah terdampak termasuk beberapa daerah yang menjadi penopang kegiatan ekonomi nasional. Provinsi yang menerapkan PSBB adalah DKI Jakarta, Jawa Timur, Jawa Barat, Banten, dan Riau. Kegiatan PSBB meliputi meliburkan sekolah dan tempat kerja; pembatasan kegiatan keagamaaan; dan/atau pembatasan kegiatan di tempat atau fasilitas umum. Akibatnya sejumlah penerbangan dihentikan, transportasi baik darat, laut, maupun udara dibatasi. Sejumlah pekerja dirumahkan dan beberapa industri berhenti berproduksi. Pergerakan manusia juga dicegah di beberapa kota dan kabupaten terdampak. Dengan demikian, aktivitas ekonomi menjadi terganggu.

Organisasi keuangan dunia IMF merilis World Economic Outlook (Juni) untuk memproyeksi pertumbuhan PDB riil dunia tahun 2020. Dengan menggunakan data yang terbaru, hasilnya menunjukkan pertumbuhan PDB riil dunia bernilai negatif 4,9\%. PDB menurut Mankiw (2016) sering dianggap sebagai ukuran terbaik dari seberapa baik suatu perekonomian berkinerja. Dengan capaian PDB riil pada 2020 yang menyentuh angka negatif, artinya kinerja perekonomian global dimasa pandemi sedang tidak baik.

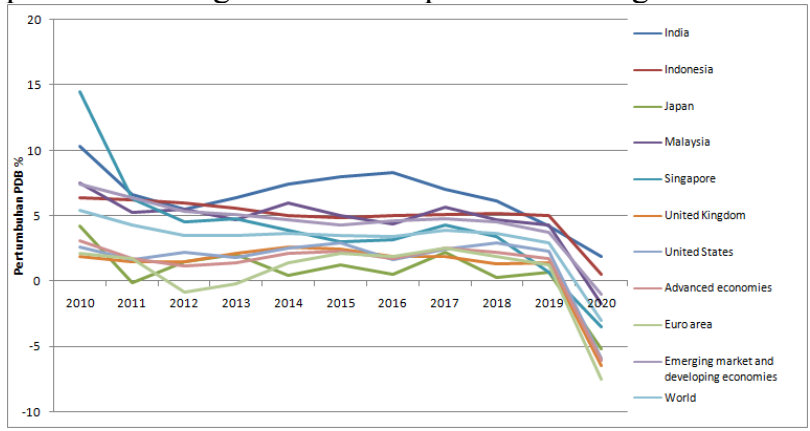

Gambar 1. Pertumbuhan PDB di beberapa negara dan wilayah

Berdasarkan Gambar 1 terlihat bahwa dari tahun ke tahun pertumbuhan PDB Riil di dunia cukup stabil. Kemudian pada tahun 2020 dimana terjadi pandemi Covid-19 membuat banyak negara di dunia mengalami kontraksi bahkan beberapa diantaranya mengalami resesi. Pada triwulan II, pertumbuhan ekonomi Indonesia menunjukkan angka $-5,32 \%$. Apabila triwulan III pertumbuhan ekonomi masih negatif maka Indonesia terancam masuk jurang resesi. Menteri keuangan RI ikut berpandangan bahwa masa depan ekonomi Indonesia akan suram, pertumbuhan ekonomi Indonesia akan tertekan sampai negatif setidaknya hingga awal 2021.

Salah satu indikator ekonomi yang digunakan untuk melihat bagaimana kondisi ekonomi Indonesia adalah indeks harga saham gabungan (IHSG) di Bursa Efek Indonesia. IHSG merupakan indikator yang sering digunakan oleh investor dalam melakukan analisis pasar modal sebelum berinvestasi. Kondisi pasar modal yang baik akan menarik investor untuk melakukan investasi sehingga akan menstimulasi aktivitas ekonomi. Kondisi perekonomian yang sedang aktif ditunjukan dengan nilai IHSG yang mengalami kenaikan. Sebaliknya, ekonomi yang sedang lesu ditandai dengan nilai IHSG yang menurun (Nurwani, 2016).

Semenjak munculnya isu tentang penerapan PSBB jilid 2 di DKI Jakarta, berbagai pihak mulai khawatir akan dampak ekonomi yang dapat ditimbulkan. Hal ini karena pada PSBB sebelumnya berbagai aktivitas ekonomi menjadi terganggu, bahkan terhenti. Dampak dari pengumuman PSBB jilid 2 terhadap ekonomi bisa terlihat dari pergerakan IHSG yang melemah. Pada 8 September lalu IHSG berada pada posisi 5.059,22, kemudian melemah hingga $4.891,46$ pada 10 September. Menurut menteri koordinator bidang perekonomian Airlangga Hartarto, IHSG anjlok akibat adanya sentimen negatif terkait pengumuman penerapan kembali PSBB oleh pemerintah DKI Jakarta.

Setelah rencana penerapan kembali PSBB Jakarta diumumkan ke publik, banyak masyarakat turut serta memberikan respon seperti pendapat, komentar, atau tanggapan. Respon masyarakat tersebut diungkapkan melalui berbagai media sosial, dan salah satu media sosial yang digunakan adalah Twitter. Dari Twitter, kita bisa melihat bahwa sentimen masyarakat terkait penerapan PSBB Jakarta dibagi menjadi sentimen positif, netral, dan bahkan negatif. Dengan demikian, penelitian ini bertujuan untuk mengetahui mengklasifikasikan sentimen masyarakat terkait penerapan kembali PSBB Jakarta serta menganalisis apakah sentimen tersebut berpengaruh terhadap pergerakan IHSG. Data sentimen masyarakat diambil dari Twitter menggunakan metode scrapping, lalu dikelompokkan menjadi sentiment positif dan negatif. Selanjutnya, untuk mengetahui pengaruh sentimen tersebut terhadap pergerakan IHSG digunakan analisis regresi logistik biner.Kemudian membandingkan metode klasifikasi pergerakan IHSG berdasarkan sentimen dengan metode regresi logistik, k-nearest neighbor, random forest, dan naive bayes.

\section{Metodologi}

Penelitian ini dilakukan dengan menggunakan data Twitter di Indonesia dan khusus membahas respon dari pengguna Twitter terhadap kebijakan PSBB jilid ke-2 yang dilakukan oleh Pemerintah Provinsi DKI Jakarta. Pada tanggal 8 September 2020 dikabarkan penerapan PSBB jilid ke-2 ini dimulai pada tanggal 14 September 2020. Namun, berita atau isu terkait PSBB jilid ke-2 ini sudah mulai terhembus sejak PSBB Transisi masih berlaku. Periode waktu yang digunakan pada penelitian ini dimulai sejak tanggal 08 September 2020 hingga 09 Oktober 2020. Selain data twitter, penelitian ini juga menggunakan data IHSG (Indeks Harga Saham Gabungan), yaitu indikator saham dalam bursa efek Indonesia yang digunakan untuk analisis lanjutan. Saham merupakan tanda penyertaan modal atas kepemilikan suatu perusahaan (Dewi dkk, 2018). 


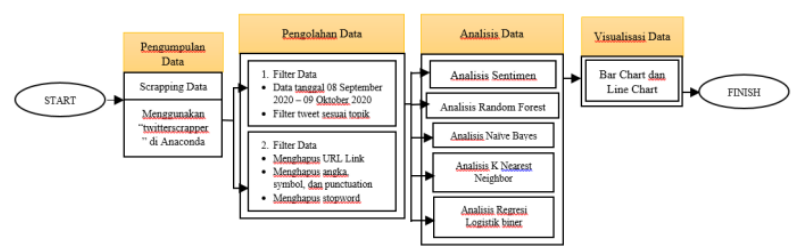

Data twitter diperoleh dengan metode web scraping dengan bantuan aplikasi Orange dan Anaconda dengan tools Twitterscrapper dengan kata kunci PSBBJakarta, IHSG. Sedangkan untuk data harga saham diperoleh dari web BEI (Bursa Efek Indonesia). Kedua data dikumpulkan dengan rentang waktu 08 September 2020 hingga 09 Oktober 2020. Data twitter yang dikumpulkan sebanyak 10.070 tweets. Data twitter yang telah diperoleh selanjutnya akan diolah dengan aplikasi orange untuk dilakukan filter data dan preprocessing text. Setelah dilakukan pengumpulan data, selanjutnya data akan di filter untuk diambil mana data yang memiliki sentimen positif dan mana data yang memiliki sentimen negatif . Sehingga data yang siap untuk dianalisis sentimen sebanyak 1.195 tweets. Analisis Sentimen merupakan cabang ilmu dari penelitian text mining atau data mining. Analisis sentimen bertujuan untuk mengekstrak atribut dari sebuah komentar (opini, sentimen, dan emosi) yang diekspresikan secara tekstual dalam sebuah halaman. Analisis ini dilakukan untuk melihat opini atau kecenderungan opini seseorang terhadap sebuah masalah atau objek. Apakah cenderung positif, negatif atau netral.

Analisis yang digunakan adalah analisis deskriptif dan analisis inferensia. Analisis deskriptif adalah analisis sentimen yang disajikan dengan menggunakan Bar Chart dan Line Chart, sedangkan analisis inferensianya menggunakan analisis regresi logistik biner yang digunakan untuk melihat hubungan respon masyarakat (opini) tentang PSBB di DKI Jakarta terhadap perubahan IHSG. Analisis Regresi Logistik merupakan suatu metode analisis yang digunakan untuk mendeskripsikan hubungan antara variabel terikat yang memiliki dua kategori atau lebih dengan satu atau lebih variabel bebas, berskala kategori atau kontinu. Beberapa macam regresi logistik, antara lain : regresi logistik biner, regresi logistik ordinal, dan regresi logistik multinomial. Model regresi logistik biner digunakan untuk menganalisis hubungan antara satu variabel terikat dan beberapa variabel bebas jika variabel terikatnya menghasilkan dua kategori bernilai 0 dan 1. Bentuk umum model regresi logistik:

$$
x=\frac{\exp \left(\beta_{0}+\beta_{1} x_{1 i}+\beta_{1} x_{2 i}+\cdots+\beta_{p} x_{p i}\right)}{1+\exp \left(\beta_{0}+\beta_{1} x_{1 i}+\beta_{1} x_{2 i}+\cdots+\beta_{p} x_{p i}\right)}
$$

Nilai $(x)$ merupakan peluang kejadian sukses dengan variabel bebas $x$ sebanyak $p$. Dalam persamaan ini, nilai $(x)$ merupakan fungsi yang non linier, sehingga perlu dilakukan transformasi logit agar diperoleh fungsi linier, sehingga kita dapat melihat hubungan antara variabel bebas dan variabel terikat. Berikut ini merupakan hasil dari transformasi logit:

Pada analisis regresi logistik biner ini terdapat beberapa uji yang harus dilakukan agar model analisis yang dibangun menjadi model yang baik. Beberapa uji tersebut, antara lain :

a. Uji Simultan (Uji F)

Uji simultan digunakan untuk mengetahui apa secara bersama - sama variabel bebas berpengaruh signifikansi terhadap variabel terikat secara keseluruhan. Hipotesis yang digunakan :

$H_{0}: \beta_{1}=\beta_{2}=\ldots=\beta_{\mathrm{p}}=0$

$H_{1}$ : Minimal ada satu, $\beta_{\mathrm{i}} \neq 0$

$$
\text { Statistik Uji G }=-2 \ln \left[\frac{\left(\frac{n_{1}}{n}\right)^{n_{i}}\left(\frac{n_{0}}{n}\right)^{n_{0}}}{\left.\prod_{i}^{n}\right) \pi_{l}\left(1-\pi_{l}\right)^{1-y_{l}}}\right]
$$

\section{b. Uji Parsial (Uji t)}

Uji Parsial digunakan untuk mengetahui apakah secara individual variabel bebas signifikan mempengaruhi variabel terikat. Hipotesis yang digunakan :

$H_{0}: \beta_{1}=0$

$H_{0}: \beta_{1} \neq 0$

$$
\text { Statistik Uji : } W=\frac{\beta 1}{s e(\beta) 1}
$$

c. Uji Kesesuaian Model

Uji ini digunakan untuk mengetahui apakah model yang terbentuk sudah sesuai untuk digunakan. Pengujian ini menggunakan Uji Hosmer and Lemeshow. Dengan hipotesis sebagai berikut:

$H 0$ : Model telah cukup mampu menjelaskan data atau model sudah sesuai

$H 1$ : Model tidak cukup mampu menjelaskan data atau model belum sesuai.

Selanjutnya dibandingkan hasil pengklasifikasian pergerakan saham dengan metode klasifikasi lain yaitu knearest neighbor, random forest, dan naive bayes.

Han, Kamber, \& Pei (2012, p. 350) menjelaskan bahwa teorema Bayes dapat menggambarkan peluang kejadian jika berada dalam suatu kondisi sehingga rumusnya adalah sebagai berikut:

$$
\mathrm{P}(\mathrm{H} \mid \mathrm{X})=\mathrm{P}(\mathrm{X} \mid \mathrm{H}) \mathrm{P}(\mathrm{H}) \mathrm{P}(\mathrm{X})
$$

Dimana $\mathrm{P}(\mathrm{H} \mid \mathrm{X})$ merupakan posterior probability atau peluang ketika kejadian $\mathrm{H}$ dalam kondisi $\mathrm{X}, \mathrm{P}(\mathrm{X} \mid \mathrm{H})$ juga posterior probability atau peluang ketika kejadian $\mathrm{X}$ dalam kondisi $\mathrm{H}$, dan $\mathrm{P}(\mathrm{H})$ merupakan prior probability atau peluang kejadian $\mathrm{H}$.

Random Forest merupakan metode yang berisi kumpulan pengklasifikasian dari Decision Tree atau Pohon Keputusan. Secara individu, Pohon Keputusan dihasilkan menggunakan sebuah pemilihan acak dari atribut di setiap node atau setiap pengklasifikasian yang terbentuk untuk menentukan pembagiannya. Lebih jelasnya lagi, setiap pohon tergantung pada nilai dari sebuah vektor acak yang disampel secara independen dan dengan distribusi yang sama untuk semua pohon di hutan. Dalam pengklasifikasiannya, setiap pohon dipilih dan kelas yang paling populer akan dikembalikan (Han, Kamber, \& Pei, 2012, p. 382 - 383).

Ibnu dan Yuniarto (2018, p. 206) mengatakan 
bahwa "KNN merupakan salah satu metode klasifikasi non-parametrik yang prinsip kerjanya mengklasifikasikan suatu objek dalam test set berdasarkan mayoritas kelas dari sejumlah $k$ tetangga terdekatnya (neighbour) dalam training set. Nilai $k$ merupakan merupakan bilangan bulat positif yang ditentukan oleh pengguna/user. Sebagai pertimbangan, semakin kecil nilai $k$ maka akan semakin rentan terhadap pengaruh noise/outlier, sedangkan semakin besar nilai $k$ maka pengaruh noise/outlier akan semakin kecil namun akan membuat batasan antar kelas menjadi lebih kabur. Untuk mencari nilai $k$ yang optimal dapat digunakan teknik cross validation."

\section{Hasil dan Pembahasan}

\subsection{Gambaran Umum}

Rencana pemberlakuan PSBB kedua di DKI Jakarta pertama kali diumumkan pada tanggal 8 September 2020. Rencana itu diumumkan oleh gubernur DKI Jakarta Anies Baswedan. Berita tersebut menuai banyak respon dari masyarakat mengingat DKI Jakarta adalah provinsi penopang kegiatan ekonomi nasional. Sosial media twitter menjadi salah satu media masyarakat untuk mengungkapkan pendapatnya. Dari respon tersebut, banyak masyarakat yang mendukung pelaksanaan PSBB kedua DKI Jakarta, namun banyak pula yang menentangnya. Berikut merupakan beberapa contoh dari respon masyarakat :

Tabel 1. Contoh Sentimen Positif dan Negatif PSBB DKI Jakarta

\begin{tabular}{|c|c|c|}
\hline JenisSentimen & Waktu & Tweet \\
\hline \multirow[t]{5}{*}{ Positif } & 10 & apresiasi \\
\hline & September & keputusan pak Anies \\
\hline & 2020 & baswedan terlepas saya \\
\hline & & sensi sama dia di \\
\hline & & pilkada Jakarta kmrn" \\
\hline \multirow[t]{9}{*}{ Negatif } & 19 & "Dear Pak \\
\hline & September & @aniesbaswedan ..saya \\
\hline & 2020 & sudah muak WFH dari \\
\hline & & $\begin{array}{ll}\text { bulan April tapi tidak } \\
\text { didukung }\end{array}$ \\
\hline & & lingkungan sekitar, \\
\hline & & $\begin{array}{l}\text { sudah banyak warga yg } \\
\text { melaporkan tapi masih }\end{array}$ \\
\hline & & banyak yg menikmati \\
\hline & & Minggu, \\
\hline & & $\begin{array}{l}\text { bagaimana ini Pak? } \\
\text { \#PSBBJakarta" }\end{array}$ \\
\hline \multirow[t]{3}{*}{ Negatif } & 16 & "Bayangin di bunderan \\
\hline & September & senayan yang kayak gini \\
\hline & 2020 & $\begin{array}{l}\text { lewat gagallah PSBB } \\
\text { jakarta :))" }\end{array}$ \\
\hline
\end{tabular}

Dari contoh beberapa tweet di atas, sentiment yang negatif menunjukkan bahwa kebijakan PSBB masih gagal dilaksanakan. Sedangkan sentimen positif menunjukan bahwa PSBB perlu dilakukan untuk mencegah covid-19 semakin menyebar dengan signifikan. Berdasarkan gambar 3. hasil pengolahan analisis sentiment menunjukkan bahwa sebanyak 573 tweet masyarakat di twitter beropini positif dan 672 tweet masyarakat di twitter beropini negatif.

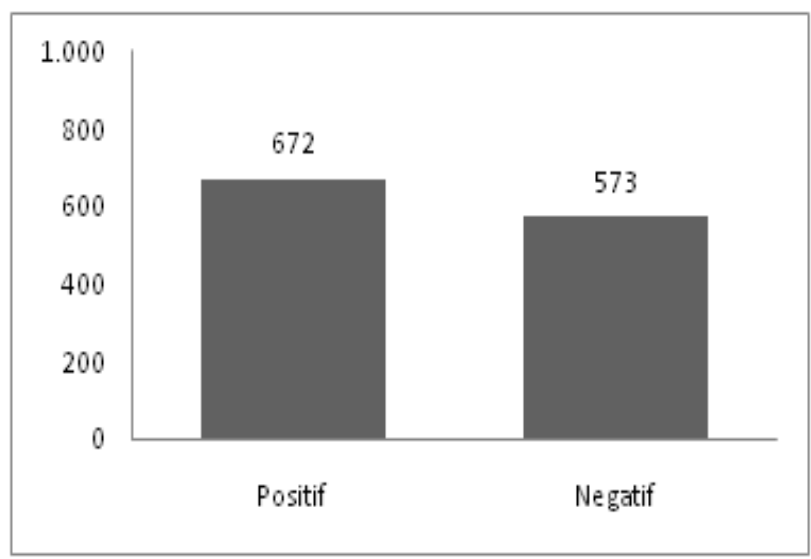

Gambar 3. Frekuensi Sentimen Masyarakat di Twitter

Selain melihat sentiment masyarakat di twitter mengenai kebijakan PSBB, penelitian ini juga melihat efek dari sentiment tersebut terhadap Indeks Harga Saham Gabungan (IHSG). Berikut adalah kondisi IHSG pada periode 8 September 2020 hingga 9 Oktober 2020. Dari gambar berikut (gambar 4) terlihat bahwa IHSG berfluktuasi setiap harinya namun mengalami tren menurun pada periode pelaksanaan PSBB di tanggal 14 September 2020.

\section{IHSG}

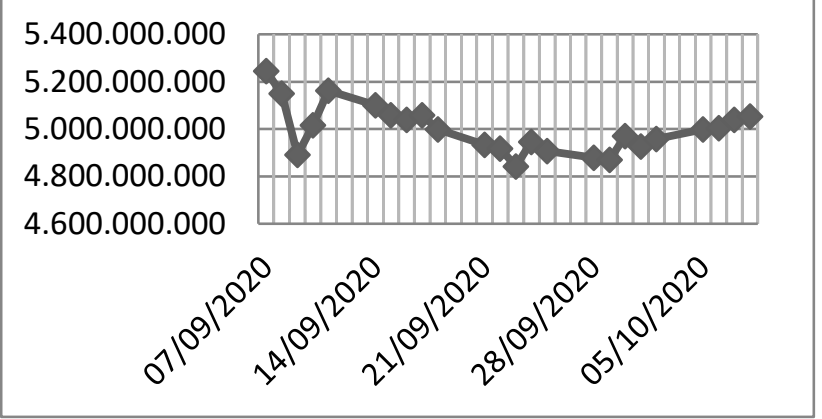

Gambar 4. Tren pergerakan IHSG 8 September - 9 Oktober 2020

\subsection{Pemodelan Efek Sentimen terhadap IHSG}

Untuk melihat apakah terdapat efek sentiment terhadap harga saham digunakan pemodelan dengan menggunakan regresi logistic biner. Model yang terbentuk adalah sebagai berikut :

$$
\begin{gathered}
\ln \left(\frac{\pi_{i}}{1-\pi_{i}}\right)=-0,338-0,146 \text { Negatif } * \\
*-0,035 \text { Positif }
\end{gathered}
$$

Dari persamaan IHSG di atas bisa diketahui bahwa ketika sentimen negatif bertambah satu, maka kecenderungan nilai IHSG naik adalah sebesar 0,8642 . Sebaliknya apabila nilai sentimen positif naik satu maka kecenderungan nilai IHSG naik adalah sebesar 0,9656 . 
Hasil ini menunjukkan bahwa jika sentiment atau respon masyarakat positif maka harga saham cenderung turun namun tidak signifikan secara statistik, sedangkan jika sentiment atau respon masyarakat negatif maka harga saham secara signifikan memiliki kecenderungan untuk turun yang lebih besar.

Tabel 2. Hasil Uji Omnibus dan Hosmer Lemeshow IHSG

\begin{tabular}{lcl}
\hline Pengujian & Signifikansi & Keputusan \\
\hline Omnibus & Tolak H0 & 0.049 \\
Hosmer Lemeshow & Gagal Tolak H0 & 0.471 \\
\hline
\end{tabular}

Hasil pengujian Omnibus menunjukkan bahwa perubahan variabel independen berpengaruh secara signifikan terhadap model. Sedangkan hasil pengujian Hosmer dan Lemeshow menunjukkan bahwa model yang terbentuk sudah fit.

Tabel 3. Ketepatan Klasifikasi Model

\begin{tabular}{lllll}
\hline Prediksi & \multicolumn{4}{l}{} \\
\hline \multirow{2}{*}{ Observasi } & Turun & 10 & 3 & 76.9 \\
& Naik & 3 & 8 & 72.7 \\
Overall Percentage & & & 75.0 \\
\hline
\end{tabular}

Tabel 3 menunjukkan hasil ketepatan model. Hasilnya adalah prediksi dari model yang terbentuk sebesar $75 \%$ diklasifikasikan dengan tepat.

3.3 Perbandingan Metode Klasifikasi

Tabel 4. Perbandingan Metode Klasifikasi

Metode Klasifikasi

\begin{tabular}{lllll}
\hline & $\begin{array}{l}\text { Regresi } \\
\text { Logistik } \\
\text { Biner }\end{array}$ & $\begin{array}{l}\text { K-Nearest } \\
\text { Neighbor }\end{array}$ & $\begin{array}{l}\text { Random } \\
\text { Forest }\end{array}$ & $\begin{array}{l}\text { Naïve } \\
\text { Bayes }\end{array}$ \\
Akurasi & $75 \%$ & $70 \%$ & $60 \%$ & $70 \%$ \\
\hline
\end{tabular}

Berdasarkan tabel diatas terlihat bahwa dari hasil perbandingan antara beberapa metode klasifikasi, metode yang menghasilkan akurasi paling tinggi adalah dengan regresi logistik biner. Selanjutnya, dibawah regresi logistik biner terdapat naïve bayes dan k-nearest neighbor dengan masing-masing akurasi 70\%. Dan yang terakhir yaitu metode random forest dengan hasil akurasi sebesar $60 \%$.

\section{Kesimpulan}

Berdasarkan hasil dan pembahasan dalam penelitian ini, respon terhadap kebijakan PSBB didominasi oleh respon positif. Dari dominasi dari respon tersebut diketahui bahwa masyarakat mendukung kebijakan PSBB karena dinilai akan efektif mengurangi kasus penyebaran Covid19. Sedangkan masyarakat dengan sentimen negatif beranggapan bahwa kebijakan PSBB yang dilakukan gagal karena masih terdapat banyak pelanggaran. Model regresi logistik yang terbentuk fit digunakan untuk menggambarkan hubungan antara respon masyarakat dengan pergerakan IHSG. Jika banyak dihasilkan sentimen negatif, IHSG memiliki kecenderungan untuk turun yang lebih besar dibandingkan jika sentimen positif. Hal ini didukung juga oleh fakta di lapangan ketika opini publik buruk terhadap suatu kebijakan atau situasi, maka akan IHSG akan cenderung turun karena para investor di pasar modal lebih memilih untuk menarik sahamnya. Kemudian, hasil perbandingan klasifikasi menunjukkan dalam kasus ini metode regresi logistik memiliki akurasi tertinggi. Dengan perbedaan yang tidak besar, posisi selanjutnya ditempati metode k-nearest neighbor dan naive bayes. Dengan demikian metode random forest menempati di posisi terakhir. Dalam penelitian ini terdapat beberapa keterbatasan khususnya terkait jumlah sampel. Ini diakibatkan oleh beberapa faktor yaitu, pertama waktu penerapan PSBB kedua di DKI Jakarta hanya berlangsung kurang dari satu bulan yaitu secara resmi sejak 14 September hingga 10 Oktober 2020. Kedua, bursa efek Indonesia hanya beroperasi pada hari kerja saja (seninjumat) sehingga naik turunnya IHSG hanya diketahui pada hari-hari kerja tersebut.

\section{Daftar Pustaka}

[1] Anoraga, P. and Pakarti, P., 2008. Pengantar Pasar Modal. Jakarta: Rineka Cipta.

[2] Agresti, Alan. Categorical Data Analysis. New York: Inc. John Wiley and Sons.2002.

[3] Block, E., 1977. How public opinion is formed. Public Relations Review, 3(3), pp.5-16.

[4] Cao, Z., Kilic, O. and Wang, X., 2020. Investor Attention, Divergence of Opinions, and Stock Returns. Journal of Behavioral Finance, pp.1-15.

[5] Dave, K., Lawrence, S.,\& Pennock, D.M.(2013) Mining the peanut gallery : opinion extraction and semantic classification of product reviews. Proceedings of International World Wide Web Conference(WWW'03), 1-3

[6] Dewi, Gusti Ayu,dan Diota. 2018. P V. Investasi dan Pasar Modal Indonesia. Depok: PT Rajagrafindo Persada.

[7] Dyah, Evita, dkk. Sentiment Analysis Using Twitter Data Regarding BPJS Cost Increase and Its Effect on Health Sector Stock Prices. Indonesian Journal of Artificial Intelligence and Data Mining (IJAIDM). Vol 3, No.1, March 2020, pp. $1-8$

[8] Hosmer, David W. and Stanley Lemeshow. 2000. Applied Logistic Regression Second Edition. New York: John Wiley \& Sons, Inc.

[9] Jiawei Han, M.K. Data Mining Concepts and Techniques third edition. Waltam:Elxevier.2012..

[10] Mankiw, N. Gregory. 2000. Macroeconomics Ninth Edition. New York: Worth Publishers.

[11] Miller, E., 1977. Risk, Uncertainty, And Divergence Of Opinion. The Journal of Finance, 32(4), pp.11511168.

[12] Nurwani, 2016, Analisis Pengaruh Inflasi, Nilai Tukar Rupiah, Dan Suku Bunga SBI Terhadap Pergerakan Indeks Harga Saham Gabungan Di Bursa Efek Indonesia, Jurnal Ilmu Ekonomi dan 
Studi Pembangunan, Vol 16, No 2 (2016)

[13] Pemerintah Indonesia. 2020. Peraturan Pemerintah Republik Indonesia Nomor 21 Tahun 2020 tentang Pembatasan Sosial Berskala Besar Dalam Rangka Percepatan Penanganan Corona Virus Disease 2019 (COVID-19). Lembaran RI Tahun 2020 No. 91. Jakarta : Sekretariat Negara.

[14] Scherbina, A., 2001. Stock Prices and Differences of Opinion: Empirical Evidence that Prices Reflect Optimism. SSRN Electronic Journal,.

[15] Pramana, S., Yuniarto, B., Mariyah, S., Santoso, I. and Nooraeni, R., 2018. Data Mining Dengan $R$ : Konsep Serta Implementasi. Bogor: In Media, p.206. 